University of Louisville

ThinkIR: The University of Louisville's Institutional Repository

\title{
Concealment and construction of knightly identity in Chretien's romances and Malory's Le morte Darthur.
}

Taylor Lee Gathof

University of Louisville

Follow this and additional works at: https://ir.library.louisville.edu/honors

Part of the English Language and Literature Commons, and the European Languages and Societies Commons

\section{Recommended Citation}

Gathof, Taylor Lee, "Concealment and construction of knightly identity in Chretien's romances and Malory's Le morte Darthur." (2014). College of Arts \& Sciences Senior Honors Theses. Paper 88. http://doi.org/10.18297/honors/88

This Senior Honors Thesis is brought to you for free and open access by the College of Arts \& Sciences at ThinkIR: The University of Louisville's Institutional Repository. It has been accepted for inclusion in College of Arts \& Sciences Senior Honors Theses by an authorized administrator of ThinkIR: The University of Louisville's Institutional Repository. This title appears here courtesy of the author, who has retained all other copyrights. For more information, please contact thinkir@louisville.edu. 
Concealment and Construction of Knightly Identity in Chretien's Romances and Malory's Le Morte Darthur

\author{
By \\ Taylor Lee Gathof \\ Submitted in partial fulfillment of the requirements \\ for Graduation summa cum laude \\ University of Louisville
}

May, 2014 


\section{Introduction}

This paper will discuss the phenomenon of well-known, high-born, strong knights concealing their identity in specific situations in twelfth-century and fifteenth-century romances. Specifically, I want to analyze Chretien's Knight of the Cart and Knight with the Lion and Sir Thomas Malory’s Le Morte Darthur, particularly the sections “The Noble Tale of Sir Lancelot du Lake,” “The Noble Tale of Sir Gareth of Orkney,” “The book of Sir Tristram de Lyonesse,” and “The Tale of Sir Lancelot and Queen Guinevere.” The twelfth century in France to the fifteenth century in England is a large leap in culture, space, and time, but both of these works function in a similar way: they idealize the chivalric practices, social codes, and knighthood of the Middle Ages. Early French romances served as sources for Malory’s Le Morte Darthur; even Chretien cites a "French Book" that is a source for his romances. These texts build upon a literary tradition: the story of Arthur and his knights. For Chretien, this tradition is still young with names such as that of Lancelot and Arthur needing to be established. For Malory, the name of Arthur and Lancelot are widely known, and his work expounds upon their names and literary history.This topic merits further study, because many of the relevant secondary materials published on these works fail to take an in-depth look at the phenomenon of knights purposefully disguising and concealing their identities, the motivations for anonymity, and the impact of this anonymity or rather the consequences of anonymity.

Many scholars have studied and published work pertaining to Chretien’s romances, especially The Knight of the Cart and The Knight with the Lion. Many interpretations of these works focus on love, viewing love as an all-important theme in the work. Scholars have variously interpreted The Knight of the Cart as a condemnation of the "ideals of love" presented by Chretien throughout the story, a "cynical,” “critical,” or "ironic” representation of love, and, 
contrarily, a love story in which "Lancelot as a lover can be taken quite seriously" (Baron 371374). Similarly, The Knight with the Lion has been interpreted as centrally focusing on love and on the neglect of love as shameful (Duggan 115-119). Even though the The Knight of the Cart and The Knight with the Lion appear to be simultaneously occurring due to the stories' referencing of one another, few scholars choose to interpret the two romances intertextually. The few works that have done so view them as a "super romance” that constitutes “Chretien’s most profound statement on the nature and power of human love," or as a work in which Lancelot, who descends into shame for love of Guinevere throughout the story, and Yvain, who seeks to free himself of shame from neglecting love, “counter” one another (Uitti and Freeman 65, 89 and Duggan 118). Such interpretations fail to take an in depth look at the phenomena of two, honorable, strong, well-known knights purposefully disguising and concealing their identities. Yvain's concealment of his identity is considered a mere ploy to "return to his lady's favor" and Lancelot's anonymity is reduced to a literary device allowing “courtly love” to define Lancelot's identity through Guinevere’s revealing of Lancelot’s name (Duggan 118 and Soudek 221).

More recent scholarship on twelfth century romance has begun to explore the relation of naming to identification and armor to identity. In the recent article "The Man with No Name: Identity in French Arthurian Verse Romances,” Sarah E. Gordon argues that going “incognito” challenges "the Romance conventions of naming and reputation" and argues that the concealment of identity paradoxically constructs identity at the same time (69). The article "On Armor and Identity: Chretien and Beyond," discusses armor's ability to "constitute identity” in Romance works and the way in which identity is "figured" in Chretien's romances (Lacy 365). Although these articles do not focus on any one specific text, providing a more general observation of twelfth century romance, they provide useful insight into the conventions of 
twelfth century romance and the ways in which the concealment of identity challenges these conventions.

Similarly, much scholarly work has been published on Malory’s Le Morte Darthur, but this body of interpretations has a much broader range than that of Chretien's romances. The work has been interpreted as expressing the "political concerns" of the fifteenth century, as questioning whether Lancelot is "a martyr for the 'religion of love”" or "a saint martyred by love”, and as a "spiritual journey” that begins with Lancelot's "encounter with the grail” and culminates with Lancelot's death which in turn can be interpreted as a "triumphal entry into heaven” (Radulescu 69; Sweeney 73; and Dosanjh 63). Some articles even discuss other aspects of identity exploration with in Le Morte Darthur. For example, in an article on women in Le Morte Darthur, it is argued that female characters play a vital role in constructing knightly identity by "providing knights with opportunities to prove their abilities or serving as rewards for their prowess” (Davidson 21). In this article, though, instances of concealment of identity are never discussed. Another article by the same author, "Prison and Knightly Identity,” discusses Malory's use of imprisonment to "reconsider the nature of knightly identity" through "redefining prowess as an aspect of self, superseding even the knight's physical actions” (Davidson 62). This article also offers no take on instances of concealment of identity as significant to knightly identity.

A few scholars have addressed the practice of knights' concealing their identities, with each scholar seeking to argue the function going incognito serves for knights. An early article, “Narrative treatment of name in Malory's Morte D’Arthur, discusses naming and identity within the work, but reduces examples of anonymity to instances of a knight "proving his worth" outside of that attached to his name/heritage (Mahoney 648-649). In the article the author states, 
"Identity is all important in the Malorian world" (Mahoney 648). If this is the case, then why is more significance not given to the instances where identity is withheld? The article "The Tristram Section of Malory's Morte Darthur" discusses instances of concealment of identity, but Schueler views instances of both Lancelot and Tristram's concealment of identity as Malory's method of comparing the two knights (Schueler 57-58). The article "Comedic Preludes to Lancelot’s ‘Unhappy’ Life in Malory’s Le Morte Darthur” takes an in-depth look at instances of "mistaken identity and disguise" in the work, purporting that these incidents "revolve around unmasking Lancelot's public persona, either through undress or disguise, to reveal his fears, his vulnerability, and his conflicts in loyalty that will help destroy the entire kingdom” (Jesmok 26, 40). Although this article does briefly explore the topic of hidden identity as a manifestation of the conflicting loyalties that I wish to discuss, the article does not significantly explore the role of concealment of identity in the renegotiation or construction of knightly identity, but merely questioning identity. Other scholars have argued that going incognito serves to win renown, prove worth, repair an identity damaged by transgressions against a lover, or prevent the use of magic (Crane 63-79; Drewes 17-25).

Through employing a cultural studies method, analyzing instances of concealed and hidden identity in Chretien's romances and Malory's Le Morte Darthur, and applying relevant scholarship to these works, I will argue that The Knight of the Cart, The Knight with the Lion, and Le Morte Darthur challenge Romance conventions and renegotiate knightly identity through the concealment of identity. Specifically, I argue that in The Knight of the Cart and The Knight with the Lion both love and shame incurred through the neglect of love serve as vehicles, or catalysts, that prompt and allow for the concealment of knightly identity. Knights find themselves caught between conflicting loyalties and duties to their brothers in arms and their 
ladies, resulting in the need for anonymity to relieve these contradictions. This renegotiation of knightly identity through anonymity in these two works does the cultural work of showing knights in a new role or identity: an identity constructed by deeds rather than naming and reputation that challenges twelfth century naming conventions; an identity free of courtly and brotherly loyalties or expectations during a time when knights were pressured to fulfill often conflicting duties to their brothers in arms and lovers in order to accurately embody the chivalric order (Farina 94). What I mean by "cultural work" is that the text works to create culture as it also reflects the culture of the author's time period. I argue that these works create culture by depicting a "new role" available to a knight. I will also argue that Le Morte Darthur renegotiates knightly identity through instances of anonymity. Furthermore, I argue that knights' concealment of identity in Le Morte Darthur challenges the values and conventions of Arthur's kingdom as well as naming conventions and that avoiding conflicting loyalties and obligations prompt for anonymity. Concealment of identity in Le Morte Darthur also does the cultural work of showing knights with an identity constructed by deeds, but also shows knights in a role that is not just outside of Arthur's kingdom, but opposing it.

\section{Concealment of Identity as a Theme}

In Chretien's Knight of the Cart and The Knight with the Lion and Malory's Le Morte Darthur instances of knight’s concealing or disguising their names, or identity, are very common. Large portions of the texts are often devoted to knights while they are in disguise or unknown. In The Knight of the Cart, Lancelot goes incognito not once, but twice. As previously discussed, Lancelot's identity is hidden during the beginning of the text until about half way through when Guinevere reveals Lancelot's name during his battle with Meleagant (Chretien 
170-215). After saving the Queen, Lancelot assumes anonymity again when captured by Meleagant, escaping captivity briefly to fight anonymously in a tournament held by the ladies of King Arthur's court (Chretien 243).

Yvain also conceals his identity multiple times in The Knight with the Lion. Yvain conceals his identity through invisibility at Laudine's castle (Chretien 275). He also forgets his identity when he descends into madness after experiencing public shame for breaking his promise to his wife (Chretien 290-292). Not long after his episode of madness, Yvain then assumes his identity as "the Knight with the Lion" until the ending of the story (Chretien 300338). During his time as the Knight with the Lion, Yvain battles Gawain, who is also concealing his identity (Chretien 327-330).

Le Morte Darthur is indeed a much longer work than the romances of Chrétien, with many more instances of knights concealing their identities. Disguise is used from the very beginning in the conception of King Arthur, when his father King Uther disguises himself as the Duke of Tintagel and impregnates the duke’s wife, Igraine with Arthur. Merlin, a notorious practitioner of magic often disguises himself. In the end of “The Tale of Balin and Balan,” both Balin and Balan are disguised and unrecognizable to one another because they are wearing different armor, which leads to great misfortune when they battle and ultimately kill one another (Malory 46-49). In “The Noble Tale of Sir Lancelot du Lake,” Lancelot conceals his identity to fight against King Arthur and his knights in a tournament and disguises himself in Kay's armor to fight against four of Arthur's Knights of the Round Table (Malory 101-103, 112-113). For most of his story, Gareth, brother of Gawain, conceals his identity from Arthur and his fellowship and also fights incognito against the Knights of the Round Table in a tournament, clashing weapons with his brother multiple times (Malory 120-168). 
Although many scholars view the "Book of Sir Tristram de Lyonesse” as a digression from the main plot and off-topic, the section folloes similar patterns as the rest of the work and instances of hidden, concealed, and disguised identity abound: Sir Tristram disguises himself as Sir Tramtrist while in Ireland, conceals his identity in multiple tournaments against Knights of the Round Table, and loses his mind and identity after losing the love of La Belle Isode; Lamorak disguises himself in a tournament; Tristram and Lamorak fight incognito; Lancelot and Tristram unknowingly fight three times; Lancelot loses his mind and identity when Queen Guinevere forsakes him and he becomes “Le Chevalier Malfait”; and Gareth, Dinadan, and Palomides disguise their identities during tournaments with Tristram as well (Malory 169-309). During the quest for the Sangrail, Galahad picks fights in which his identity is concealed but others tend to reveal his name (Malory 329, 373). And in the final sections of the work, Lancelot hides his identity as Guinevere’s lover from the public, fights for Guinevere’s honor while incognito, disguises himself in two tournaments against Arthur, and Gareth disguises himself in a tournament as well (Malory 403-404, 413-420, 437-443). With instances of anonymity occurring so frequently in and consuming much of these works it seems that knights' concealment of their identity serve some importance.

\section{Why Go Incognito}

Among the scholarship considering the significance of knights’ concealing their identity, scholars have explored the reasons why knights would want to go incognito. In an article on knights in disguise, Susan Crane discusses how romances “define identity in moments when knights disguise themselves or dress up in the badges and regalia of orders of knighthood" (Crane 63). Crane argues that "chivalric incognito, as a motif of romance and as a historical 
practice, amounts to a peculiar kind of self-presentation, a self-dramatization that invites rather than resists public scrutiny” (Crane 63). Crane’s article briefly discusses the debates over medieval subjectivity and the place of individuality during the Middle Ages; scholars view the conception of individuality as either a medieval as well as modern phenomenon or solely a modern conception; knights are either struggling to match up their versions of self with their public persona or their identities are exclusively determined by the public (Crane 63-65). Conception of individuality here means whether individuals recognized their own private identity separate from that which the public assigned them, or whether identity was purely the property of the public and assigned by society. Private identity describes an individual's sense of self and public identity describes the label that society prescribes for an individual. Crane argues a third, or rather middle-of-the-road, argument in which she suggests that

an individual identity can be founded in renown in this period when the individual had not yet become the questioning opponent of social precedent. Accorded by the chivalric community, this individuality derives from, rather than precedes, public judgment. (Crane 65)

For Crane, complete conception of individuality does not appear in medieval romances, but some notion of individuality can be achieved through the winning of renown. Crane argues that another "potential for private identity” results when there is a “conflict within the community’s judgment, or between the adventuring knight's self-assessment and the assessment of his peers, a space opens up for an identity that is beyond the reach of public determinations” (Crane 76).

Crane identifies two situations in which knights go incognito: those seeking to prove themselves and those who have committed offenses against their lovers. Crane argues that in all these cases, chivalric incognito is a public act, one of definition and 
redefinition that speaks to onlookers. Incognito does conceal information, but does so only temporarily in order to focus attention on the judgment of present actions without regard for lineage, past achievements, or past failures (Crane 67). Basically Crane sees the knights' concealment of identity as a way to re-construct, change, or add to—essentially modify—-their identity. For example, Crane sees Yvain's concealing of his true identity and assuming the role of the "knight with the lion" as his way of reconstructing his "manhood," or rather public identity, in deeds of chivalry after his public identity is damaged through public shaming (Crane 68). The function of chivalric incognito according to Crane is to "establish or revise the perception of others concerning the disguised knight's merits" (Crane 70). Furthermore, the "full semiosis of incognito" involves a knight shedding his disguise and the renown earned being incorporated into his previous identity. While this argument can explain many instances of incognito, it cannot explain instances in which a knight fights incognito and does not reveal his name, or laments the revealing of his name such as I will point in Knight of the Cart and Le Morte Darther.

In the article “Narrative Treatment of Name in Malory’s Le Morte D’Arthur,” Dhira B. Mahoney notes that "nowhere is the ratification of Arthurian values so evident as in the continual classification, or ranking, of Arthurian knights (Mahoney 647). Mahoney points to the early French romances as sources for Malory's preoccupation with naming and knightly values. In fact, one of the few areas in which Malory deviates from his sources is in providing names for unnamed knights and often revealing the identity of unnamed knights early on rather than later as seen in Chretien's Knight of the Cart. Mahoney argues that “identity is all-important,” yet admits that there is this strange occurrence of knights concealing their identities. Mahoney writes, identity, however, is frequently withheld from his peers by an Arthurian knight 
engaged in proving his worth. In the Morte Darthur, as in much medieval romance, concealment of and subsequent revelation or discovery of identity provide a pattern in which to structure events. (Mahoney 648) Just as in The Knight of the Cart and The Knight with the Lion, knights in Le Morte Darthur often conceal their identities during adventures and go incognito in fights and tournaments. Concealment of identity can indeed be seen as a pattern that structures events in Chrétien’s romances: the stories fluctuate between the knights' concealing their identities, earning renown and being welcomed back into Arthur's court. Le Morte Darthur is a much larger work than the individual romances of Chrétien, but similar narrative patterns frequently occur within the work: knights disguise themselves and fight in tournaments or with each other, discover each others' identities, report their prowess to Arthur, and feast. While instances of anonymity do seem to drive the plot forward and provide a structure for events at times, this cannot account for all instances of anonymity in Le Morte Darthur. Also, such a frequently occurring phenomenon must be more than a mere plot device.

In “The Sense of Hidden Identity in Malory’s Mort Darthur,” Jeanne Drewes also recognizes the peculiarity of particularly well-known, world-renowned, Knights of the Round Table concealing their identities, especially when considering the special care that Malory takes to provide names for knights who are originally unnamed in their sources. Drewes discusses scholarship concerning knights' concealment of identity, such as Mahoney’s article on narrative treatment of name. Drewes agrees that hidden identity can be used to further plot and "heighten narrative suspense," but argues that "knights also hide their names to prevent the use of magic and to reaffirm knightly status” (Drewes 18). Drewes contends that name and magic are associated throughout the work, citing the example of the gold lettered names of knights on the 
back of seats at the round table, which prophesied feats they would accomplish (Drewes 20). Drewes argues that because name and magic seem to be connected at times throughout the work, that fear of the power one has over a person simply by knowing their name "accounts for a knight's reluctance to reveal his identity on some occasions" (Drewes 20). While I do agree that magic, at times, does appear to be wrought upon a person simply by knowledge of their name such as the destiny-bearing "sieges" at the Round Table or the prophetic inscriptions on swords, scabbards, tombstones, etc., I believe that reluctance to give one's name is more tied to avoidance of obligations, duties, favors, or peril that might be required of or befall a knight once another knight or person discovers his identity, an idea I will later further expand.

But for Drewes, the most compelling reason for a knight to conceal his identity is "to deceive lesser knights into fighting him," so that he might "reassert their positions through a show of superior prowess" (Drewes 21-22). In this view, the role of hidden "identity is paradoxically to support and preserve" public or social identity; "remaining nameless allows a knight freedom within the hierarchal society to reassert his position and thus maintain the power that is one with the name” (Drewes 23). While concealment of identity is very much used to trick lesser knights into fighting a stronger knight, I argue that knights are not trying to preserve name, but essentially "level-up," or increase their worship, or respect and admiration by others, and have that worship based solely in deeds. And rather than attempting to preserve their names, I argue that knights are exploring a new, previously unavailable role—one against Arthur—which rejects the values and conventions of Arthur's fellowship and allows a knight to claim his own honor and renown rather than gain honor for his lord. Drewes addresses Arthur's opposition to his best knights fighting incognito against him and the other Round Table knights but argues that Arthur does not forbid such actions because all-in-all the action brings more power to him and 
reasserts his power as the greatest and strongest king. In a later section, I argue that Arthur increasingly seems to dislike this practice.

In the article “Comedic Preludes to Lancelot’s ‘Unhappy’ Life in Malory’s Le Morte Darthur,” Janet Jesmok argues that, while many of Lancelot's early episodes of concealed identity are rather humorous and slapstick, these episodes explore Lancelot's character and expose Lancelot's problems of self and identity. Jesmok writes that these humorous sequences not only entertain but also explore Lancelot's character, prefiguring the ill-fated, or, in Malory's term, 'unhappy,' events that dominate Lancelot's fateful life and finally estrange him from the Round Table and his beloved Guinevere. In lightly but perceptively probing Lancelot's sense of self, they prepare us for later, graver incidents which result from Lancelot's inability to resolve the conflicts of his identity: is he Arthur's knight? Guinevere's? or God's? Reading these comedic preludes in tandem with the tragic events they foreshadow demonstrates Malory's grasp of character and control of theme throughout Le Morte Darthur. (Jesmok 26).

Jesmok analyzes instances of undress, trickery, others’ deceiving Lancelot, and Lancelot assuming a new identity or concealing his identity and discusses their significance in “unmasking Lancelot’s public persona” (Jesmok 40). Although Jesmok focuses on unveiling the uncanny parallels between the lighthearted, comedic adventures of Lancelot and the final events leading up to the end of Arthur's fellowship, her insight that such episodes, specifically those where Lancelot conceals his own identity, signify Lancelot’s troubling and eventually detrimental conflicts of loyalty is an important component of my argument concerning the significance of knight's concealing their identity. Jesmok identifies Lancelot's early play with 
disguise as an initial indicator of Lancelot's troubling conflicts of identity and loyalty (Jesmok 32-33). Jesmok argues instances of anonymity show Lancelot "struggling to move comfortably into the heroic persona that others see, to make his sense of self congruent with the name" (Jesmok 28). Jesmok identifies Lancelot’s conflicting social perceptions of him as both “Arthur’s greatest knight and Guinevere’s lover” as evidence of his struggle to live up to his “name.” I argue that these conflicting perceptions are not examples of Lancelot struggling to live up to his public persona, but evidence of the conflicting loyalties that lead to knights concealing their identities. Many who speak of his great name and prowess often mention his rumored love for Guinevere, but in social situations Lancelot always disputes accusations that he and Guinevere are lovers (Malory 98, 108). Guinevere and Lancelot's romance is not a fully realized part of either of their public identities; it is only a rumor. Yet it is an important and realized aspect of their private identities that each strives to balance with their public persona. Lancelot must conceal his identity as Guinevere's lover because it conflicts with his duties to Arthur and the order of knighthood. Jesmok appears to argue that Lancelot strives to make himself "congruent" with his “name," or public persona, but I argue, rather, that Lancelot is trying to escape these conflicting loyalties and that going incognito is his way of escaping.

\section{Conflicting Loyalties and Obligations}

In the recent article "The Man with No Name: Identity in French Arthurian Verse Romances," Sarah E. Gordon argues that going “incognito” challenges "the Romance conventions of naming and reputation” (69). Telling one’s name, introducing one’s self, and social reputation is expected in the world of Romance. Gordon argues that "the man with no name, who fights incognito at a tournament, is situated in a position to problematize romance 
conventions such as naming and reputation” (Gordon 79). In other words, when Yvain and Lancelot abandon their names and known identities and assume anonymity, their characters' explore the function of naming and reputation and, more importantly, what happens in their absence.

In light of Gordon’s argument, I argue that chivalric incognito challenges romance naming conventions in that the concealment of identity appears to alleviate some of the stresses, pressures, and obligations that are attached to their names. When a knight conceals his identity or refuses to give his name, he is able to remove himself from his assigned role and the obligations accompanying it. In the twelfth century, knights were expected to fulfill often conflicting duties to their brothers in arms and to their lovers or wives in order to accurately embody the chivalric order (Farina 94). A knight’s name and identity are no doubt closely tied to such obligations. In The Knight of the Cart, a knight, whose father refuses to let him fight the anonymous Lancelot, speaks of the trouble with everyone knowing your name and reputation:

It is true that a man is treated badly by close friends. I could make a better bargain elsewhere, for you want to mislead me. I realize I could display my valor more in a foreign land. No one who did not know me would interfere with my will. (Chretien 191)

Although his father is only trying to help him, this knight makes an interesting point about the nature of naming and reputation during this time: As a recognized member of that society, this knight has certain obligations (to his father and to uphold his valor) and a reputation (his father views him as lacking in prowess and too sure of himself) that he can only escape by going to another land, effectively abandoning the identity, and the obligations accompanying it, that the 
public has assigned him. This knight feels that he is being held back by those closest to him because of this social identity.

In The Knight of the Cart and The Knight with the Lion, Lancelot's and Yvain's refusal to provide their names, thus concealing their true identities, questions Romance naming conventions and the publicly assigned reputation that is attached to a person's name, which signifies one's heritage, honor, and, often times, very right to nobility and honor. When a knight has no name, the only thing left to describe him by are his deeds. An example of this can be seen through Yvain. A maiden tells her Lady that she can be sure that Yvain can help her defend her castle because he is "the most gifted and most distinguished knight on earth"; no reasons for this praise are given (Chretien 292). In opposition, when a maiden seeks help from Yvain as the Knight with the Lion, the only way she can be assured of his honor is through a description of his deeds from those he has helped. He has become known as one "who did all he could to aid women in distress," who could defeat giants so quickly he "scarcely had time to sweat," and who could defeat three knights at once (Chretien 314, 315). Similarly, when Lancelot fights anonymously in the tournament at King Arthur's court his worth is assessed simply by his deeds. At the beginning of the tournament knights who are not participating in the tournament point out the knights who are most esteemed based on their arms and reputation. For example: "He bears a shield of half green and half azure, with a leopard emblazoned on the green half. He is the covetous Ignaures, amorous and pleasing” (Chretien 240). In this example, Norris Lacy’s argument that “armor constitutes identity” in Chretien’s romances, proves true (Lacy 365). Lancelot's donning of unfamiliar armor, then, challenges this romance convention. Lancelot is only seen as "having no equal" after his performance was "so fine" that no one could declare otherwise (Chretien 243). Traditionally, tournaments are seen as a means of "reinforcing 
reputation and hierarchy," but when Lancelot fights anonymously, wins, and never reveals his identity he is not seeking to enhance his reputation, but have his deeds recognized for what they are — free of expectations based on his name and reputation (Gordon 71).

In his book exploring the "narrative of combat” in Malory’s Le Morte Darthur, Andrew Lynch agrees that "proper names are a staple of narrative interpretation" in the work (Lynch 1). Lynch identifies a long standing issue amongst critics and readers of Le Morte Darthur as the determination of "to what extent the plot claims authority over character, or vice versa," or as he terms it the "subject/object problem" of characterization; basically, how much a character is manipulated to further plot or how much the plot is manipulated to further the character (Lynch 2-3). Essentially, Lynch argues that the ultimate desire of the narrative is to "save name" (Lynch 15). Saving name in this context means to ultimately uphold the public persona: the text works to preserve Lancelot's public identity. In order for the text to save name, lesser knights, such as Balin, do appear to be objects of the narrative: they must fail, so that Lancelot's name can become greater (Lynch 15-27). While this argument seems to prove true in many cases, I argue one step further that lesser knights must fail in order to demonstrate one important aspect of Lancelot's identity: he is an essential figure to the Round Table, seeming to hold more or as much power as Arthur in many instances.

In order for the text to save name, reputations in Le Morte Darthur must possess “amazing resilience,” particularly that of Lancelot. Lynch writes that “a name, once gained, strongly resists alteration in the eyes of others" and that "others may know better than the bearer what a name is truly worth"; "the major figures of the narrative never change, only their fortunes and their context” (Lynch 6, 12). Malory's word for the "nature of individuality" is "condition," yett Malory uses this word to describe moral alignments and habitual behaviors (Lynch 13). 
"The usage in all cases shows belief in the essential habitualness of behaviour, the belief that people don’t change, even when, as in Gawain's case, their behaviour seems very inconsistent” (Lynch 13). I argue that it is in these moments where identity is withheld that the individuality and personal identity or self concept can be seen emerging: knights must go incognito because they wish to do something that is out of character; that which society would look down upon. Lynch argues that Malory's text is “underequipped to deal with notions of individuality,” thus why characters remain so static. Lynch argues that the texts inability to account for individuality may reflect aspects of fifteenth century culture, particularly the dependence of individuals upon their lords in order to gain worship and better standing (Lynch 13). I suggest that it is Arthur's world which cannot handle notions of individuality. I argue that by the end of the work, the characters are no longer static and that is exactly the problem: Lancelot and Guinevere's public identities and reputations are altered when their romance becomes known and the tensions of the Round Table explode. I also argue that knights like Tristram and Lancelot slowly but surely come to realize that they don't depend on their Kings for renown and security, but that their kings derive their renown and security from their knights.

Lynch remarks on the high importance and value that Malory places upon names and naming: in the Winchester manuscript, all names, a few places and feasts, and the word Sankgreal are all written in red so that they stand out; names account for one out of every twenty words in Le Morte Darthur (Lynch 3-4). The characters themselves are very concerned with name and identity, with eighty percent of instances of the word "name" occurring in the dialogue (Lynch 4). Drewes goes as far as to count the number of times a knight is asked for his name in a one-hundred-page sample of the Sir Tristram section of Le Morte Darthur. As it turns out, a knight's name is asked for thirty-three times, and a name is given only fifteen. And within these 
instances where name is withheld, eight different knights conceal their identities by changing their armor (Drewes 17; 24). Just as in Chrétien's romances, the knights in Le Morte Darthur realize the trouble that their names and reputations cause them. For example, Sir Lancelot is captured by the evil sorceress Morgan le Fay because she knows of his "worthiness," that he is the "most noble knight living" and wishes to have him as her husband (Malory 98-100). Sir Dinadan laments falling into the fellowship of both Tristram and Lancelot because of the attention they receive. They are often attacked, which requires him to do much battle and get wounded often (Malory 221). In a further example, King Mark tells Lancelot’s enemies that the incognito Tristram is Lancelot in hopes that they will kill Tristram because of their hate for Lancelot. It is said that King Badgemagus and Sir Galahalt intend to slay Lancelot during the tournament because "Sir Lancelot had evermore the higher degree” (Malory 248). Knights are forced to fulfill knightly obligations that they have no desire to fulfill simply because someone knows their name. For example, in sequential episodes, Lancelot's service is required by two damsels who know his name, status as a Knight of the Round Table, and reputation of great strength and prowess (Malory 113-119). In the second instance Lancelot says "since that ye know my name and require me of knighthood to help, I will do what I may to get your hawk" (Malory 117). Because they know his name, they can require him to do them service despite his will; Lancelot is bound by the orders of knighthood and chivalric values.

In Le Morte de Arthur, knights challenge naming conventions as well when they conceal their identities. Lynch identifies a pivotal moment in the text which demonstrates Lancelot's function as both an object of plot and a subject. I argue, though, that this moment, rather than suggesting that "other adventures might make him another man," demonstrates the power of revealing/concealing a name (Lynch 4-5). When Tarquin, an enemy of the Round Table, reveals 
unknowingly to Lancelot that it is Lancelot himself he so desperately seeks to shame, Lancelot says,

'Now I see well,' said Sir Lancelot, 'that such a man I might be, I might have peace; and such a man I might be, that there should be mortal war betwixt us. And now, sir knight, at thy request I will that thou wit and know that I am Lancelot du Lake, King Ban’s son of Benwick, and very knight of the Table Round. And now I defy thee, and do thy best.’ (Malory 105-106)

Lynch argues that this instance shows that a knight's name, or reputation, is “primarily the property of others” (Lynch 5). I argue one step further that, while this example does show the public possession of name and reputation, even more it demonstrates the power a knight has in choosing his identity simply by revealing or concealing his name. While Lynch and Felicity Riddy argue that different decisions concerning “adventures” are what gives Lancelot this sense of “potential other selves,” I argue that, especially given the context of Lancelot’s speech, Lancelot is referring to the man he might be if he reveals or conceals his name (Lynch 5). Lancelot is responding to Tarquin's request for his name, during which Tarquin reveals that he will let him go unless he is Sir Lancelot du Lake. If Lancelot conceals his name, he will have “peace”; if he reveals his name, there will be "mortal war” between them (Malory 105). While the public may own and exert power over Lancelot's name and reputation and construct a public identity for him which he is expected and basically required to uphold, in instances where his identity is not known Lancelot can choose to claim his socially constructed identity or conceal or disguise it: effectively choosing the man he wants to be at that particular moment.

In the following sections I will elaborate upon the functions of concealed identity discussed in the two previous sections. I will begin by discussing love and shame as catalysts for 
concealment of identity. I will then discuss the use of concealed identity in order to prove worth and earn renown. Within these sections I will also discuss how conflicting loyalties and duties are always an underlying issue. I will then discuss the most important function of chivalric incognito as a means of escaping conflicting loyalties and duties. I will also include a section addressing the fates of Balin and Sir Tristram and how they relate to the identity of Lancelot. I will conclude with a section discussing how knightly identity is renegotiated by the concealment of identity.

\section{Love, Shame, and Identity}

Although love and the shame incurred through failure to uphold love are extremely prevalent in the both The Knight of the Cart and The Knight with the Lion and may appear to be overarching "themes" of the works, love and shame often serve a different function as motivators, or catalysts, that prompt the concealment of identity in each work. In each work love or shame from neglect of love play an important role in the creation of the knights' "new" identities. In Lancelot's tale, it is "Love” that causes Lancelot to jump into the cart, thus creating his new identity as the "Knight of the Cart" (Chretien 174). Similarly, shame incurred by the neglect of love causes Yvain to descend into madness and forget his identity when his wife, Laudine, sends a messenger to publicly humiliate him and make known his failure to uphold his promise to return to her in one year's time (Chretien 289-290). Before Yvain loses his mind, the speaker says that Yvain "wanted to flee by himself to some wild land where no one would know or seek him where man or woman would know no more of him than if he had fallen into a bottomless pit” (Chretien 290). Yvain is unable to deal with public shaming, the shame of breaking an oath and failing to uphold his courtly duties to his wife, and the conflict between his 
duties to his brothers in arms and to his wife; Yvain can’t “undo” his shame, therefore he just abandons his identity altogether. Love and related shame, then, serve as vehicles leading to the concealment of identity. In other words, they drive the plot towards this strange occurrence of well-known, well-to-do, loved knights choosing to fight anonymously.

Another problem with love as the major theme of both works, is that, while there are many passages in both works discussing how “Love’s will” governs both Yvain and Lancelot, indicating that all of their actions are out of love and desire to please their beloved and arguing that love makes them stronger, better knights, there are many points in the works where love fails to uphold such functions (Chretien 174). Although Chretien states that “through Love’s great assistance” Lancelot is able to defeat Meleagant and save the Queen, the invocation of shame unrelated to love contradicts this claim (Chretien 215). Once Lancelot's true identity is revealed and he realizes that his "beloved" is watching he actually begins to lose the battle. Lancelot only begins to win the battle after his claim to "valor and excellence" is challenged (Chretien 315). Fear of shame in respect to prowess and honor, then, seems to motivate Lancelot to win the battle for the Queen against Meleagant, not love.

Likewise, Yvain's sole motivation for going to Laudine's spring is to avenge his cousin's disgrace. Yvain's sole concern when Laudine's husband, who defends the spring, flees is that "no one would believe his deed unless he returned with proof" (Chretien 268). Although Yvain claims to fall in love with Laudine, shame from failure in prowess is still an ever present motivator: "love and shame assailed him from two sides" with the shame of failure in his quest and love for Laudine detaining him from returning home (Chretien 275). Another interesting point here is that the conflicts of love and shame both cause Yvain to conceal his identity: via magic he is invisible and hiding in Laudine's castle, refusing to leave out of shame and love 
(Chretien 269). Honor and renown, though, seem to be a stronger motivator than love. Yvain refuses to leave the castle in secret, not out of love, but because "more honor" would be his if he left in plain sight (Chretien 275). Leaving in plain sight though, will result in his death. Marriage to Laudine then becomes Yvain's “honorable way out”, so to speak. Although love presents itself as a theme of both works, the presence of shame related to loss of honor and a claim to prowess as a motivator at times when love is supposed to be governing both knights, contradicts the idea that love is the sole concern of both works and places a focus on renown and deeds.

Similarly to Chretien’s romances, Malory's Le Morte Darthur is often seen as portraying love as an important theme: Tristram, La Belle Isode, Lancelot and Guinevere are "the only true lovers” and it is said that Guinevere has a happy ending because she is a true lover (Malory 201, 444). Also much attention is given to whether knights fight for "love or wrath" (Malory 256). Just as in Chretien's Romances, love and shame are catalysts for the concealment of identity. For example, Lancelot conceals his identity in order to save Queen Guinevere from being burned because of accusations that she intended to murder Gawain with a poisonous apple (Malory 408414). The queen has banished Lancelot from the kingdom out of anger and jealousy of his toil for other women and then finds herself in great peril and no one willing to fight for her. Lancelot asks Sir Bors, his relative, to act as if he will fight for the queen, all the while waiting for Lancelot to appear incognito the day of the battle. Lancelot shows up with a "strange shield of strange arms" so that "there was not one that knew him but if it were Sir Bors" and saves the day (Malory 411-412). Lancelot and Guinevere’s relationship prompted this act of anonymity.

In further example, when Sir Tristram suspects La Belle Isode of being untrue to him, he falls into great sorrow, resulting in madness (Malory 213-217). Similarly to Yvain’s episode of madness, Tristram runs naked into the forest and appears primitive. Even after he has been 
discovered, taken into the castle of Tintagel, and remembers who he is, he keeps his name hidden so that "all this while there was no creature that knew Sir Tristram, nor what manner man he was” (Malory 216). When Isode discovers Tristram and rejoices, he responds, "go from me, for much anger and danger have I escaped for your love” (Malory 217). Love and heartache drive Tristram to anonymity. Tristram also mentions the trouble and conflict that their love has caused him, such as his conflicting loyalties to his King and Uncle, Mark, and La Belle Isode. King Mark marries La Belle Isode, causing Tristram to be caught between two conflicting desires to remain loyal and faithful to each.

Lancelot is also victim of madness when Queen Guinevere forsakes him because he is tricked into intimacy with King Pelles’s daughter, Elaine, not once but twice, and impregnates her with Sir Galahad on their initial encounter (Malory 284-285, 287-288). Lancelot becomes “as wild as ever was man,” living off of fruit and water, and finding himself in various fights (Malory 288-298). Once Lancelot is healed by the Sangrail, he remembers his name, but decides to assume a new identity, "Le Chevalier Malfait,” or "the knight that hath trespassed” (Malory 299). As Le Chevalier Malfait, Lancelot defeats five hundred knights in a tournament. He abandons his new identity after a long battle with Percival, a brother of Gawain (Malory 300302). Similar to Yvain, Lancelot assumes a new identity once he has been shamed. Lancelot's battle with Percival forces Lancelot's identity into the open, requiring him to go back to King Arthur's court. Once again, concealment of identity and assuming a new identity relieves the pressure of conflicting loyalties and shame. Also, the revelation of Lancelot's identity forces these obligations and shame back upon Lancelot. For example, when Sir Ector pleads with Lancelot to return to Arthur's court, Lancelot refuses because of his shame and transgression. 
Only after being reassured that all is forgiven and his reputation intact, Lancelot returns to Arthur's court (Malory 302-303).

Finally, an important example of concealed identity as a result of love, which could be termed more accurately as a "social disguise," is that of Lancelot attempting to hide and conceal his and Guinevere’s love. I consider this as a concealment of Lancelot's identity because, although it is rumored that he and Guinevere's relationship might be more than platonic, Lancelot's identity as Guinevere's lover does not seem to form an actual part of his public name and reputation, merely a rumor attached to them. For example, when confronted by a damsel concerning his unwedded state and rumored love for Guinevere, Lancelot says, I may not warn people to speak of me what it pleaseth them; but for to be a wedded man, I think it not; for then I must couch with her, and leave arms and tournaments, battles and adventures. And as for to say take my pleasance with paramours, that I will refuse, in principle for dread of God. For knights that be adventurous should not be adulterers nor lecherous, for then they be not happy nor fortunate unto the wars; for wither they shall be overcome with a simpler knight than they be themselves, or else they shall slay by unhap and their cursedness better men than they be themselves. And so who that useth paramours shall be unhappy, and all thing unhappy that is about them. (Malory 108)

Jesmok does not take a stance on whether this is a "social disguise" of Lancelot to hide his affair with Guinevere or if Lancelot really thinks that their love and relationship is not immoral, but I argue that Lancelot's actions later in the text reflect that this speech is merely a social disguise. Also, the "unhappiness" that Lancelot argues will follow a knight that takes a paramour is exactly the unhappiness that befalls Lancelot by the end of the work: he kills many good knights 
and friends and King Arthur's fellowship ends. Jesmok continues on to say later in the article that Lancelot’s “devotion [to Guinevere] has made him Arthur's greatest knight” and that "betraying Guinevere pits him against the Round Table and Arthur” (Jesmok 36). I argue the converse of these ideas: Lancelot's devotion to the queen seems only to complicate his knightly identity; worshipful renown and reputation are his only concern. Only when King Arthur becomes convinced that the rumors are true does the relationship become part of his identity, which has detrimental effects on Arthur’s fellowship and kingdom.

For the knights in these three works, love causes complications in their lives. Love causes knights to have conflicting duties and obligations: those to their brothers in arms and King, and those to their wives or lovers. Yvain is torn between his husbandly duties and his knightly orders when Gawain warns him not to become like men "who are less worthy because of their wives (Chretien 286-287). Lancelot must avoid the people of Logres' pleas to free them from evil so that he can save Guinevere (Chretien 199). In Le Morte Darthur, Lancelot's relationship with Guinevere obviously conflicts with his obligations to Arthur and the revelation of their relationship is the final straw in the vast pile of mounting tensions in Arthur's fellowship. In instances of anonymity relating to love in these works, it is clear that anonymity and creating a new identity relieve these contradictory and conflicting obligations and duties.

\section{Concealment of Identity, Proving Worth, and Earning Renown}

Proving worth and earning renown indeed seem to be important themes in chivalric romances. Lancelot and Yvain's anonymous adventures in Chretien's romances could be viewed as examples of a knight using concealment of identity in order to prove their worth. In Yvain's case, he is publicly shamed when his offenses against his wife become known. For Yvain, then, 
going incognito and assuming the identity of the Knight with the Lion is an act of identity "redefinition," to use Crane’s words. By abandoning his old identity and assuming a new one, Yvain is able to focus the attention on his current acts without any repercussions from his old identity. Yvain is able to construct an identity based on deeds and "re-prove" his worth and renown. When Yvain, with the help of his wife's maiden, Lunete, finagles his way back into good graces with his wife, he argues that he has redeemed himself for his transgressions against her through his actions as the Knight with the Lion:

I have paid for my ignorant action, and I wish to pay for it still. Folly made me stay away, and I acknowledge my guilt and disgrace. I have been most bold to dare come before you. But if you would allow me to stay, I will never wrong you again. (Chetien 338)

Yvain has tricked Laudine into promising she will grant the Knight with the Lion her assistance in appeasing the wrath of his lady, but then reveals that he is her husband whom she despises. In this quote, Yvain argues that he has redeemed himself and proved he is worthy of Laudine's love again through his actions as the Knight with the Lion: he has defeated giants for the defenseless, rescued maidens and settled their quarrels. Yvain claims that he has done all of this knightly service to prove his love for his wife and that he is worthy of her love because of his valiant actions.

Underlying his desire to prove his love and worth, though, is Yvain’s desire to be accepted back into his old life and to rid himself of the shame he has experienced. As long as he is the Knight with the Lion, he need not worry about his obligations to the Knights of the Round Table or his wife. He can even choose what battles he fights. For example, when a family related to Gawain asks for Yvain's service, he initially refuses because he is on his way to save Lunete, 
who knows his true identity and requires his service (Chretien 305). Had the family known his name, it would have been very shameful to refuse them in their time of need and extremely disrespectful to his brother in arms, Sir Gawain. Once Gawain discovers that Yvain and the Knight with the Lion are one in the same, Yvain is thrown back into his world of conflicting duties and damaged reputation; he is confronted again with his shame and must erase the damage to his reputation. Reconciliation with Laudine is his only way to repair his public identity and be completely accepted back into society. His chivalric incognito and identity as the Knight with the lion then become a method of repairing the shame he has incurred through neglecting these obligations. While his anonymous adventures may prove his worth and bring renown, anonymity for Yvain, is a direct result of shame, a method of avoiding conflicting loyalties to his wife and brothers in arms, and repairing the damage caused by conflicting obligations.

Similarly, in The Knight of the Cart, Lancelot's anonymous tournament battle can be viewed as an attempt to prove his worth and earn renown. Lancelot briefly escapes imprisonment by Meleagant to fight in a tournament held by King Arthur. Upon learning of the tournament Lancelot becomes distraught because he "cannot be where all is good in the world will be"; he will not have the opportunity to prove himself as the best knight (Chretien 236). Lancelot attends the tournament, "burning with desire to show all of his valor" (Chretien 242). After winning the tournament, it is said that Lancelot's "own worth was, in effect, too great” for him to consider taking one of the noble ladies there as his wife. All hail the "knight with the vermilion shield" as having no equal (Chretien 243). Lancelot's worth has skyrocketed. While Lancelot may have previously been known as one the best of Arthur's knights, he is now known as one of the best in the world because he has "defeated all the knights in the world" and has proved that he is "worth a thousand of those on the field” (Chretien 243). 
Although Lancelot's anonymous deeds in the tournament do seem to prove his worth and gain him much renown, elimination of conflicting loyalties plays a large factor in proving this worth. By concealing his identity and ties to King Arthur's Court, Lancelot is able to prove his worth as greater than all knights, even those of the Round Table. According to Crane's argument, the "full semiosis of incognito" occurs after a knight reveals his true identity and incorporates the renown earned while in disguise into his public identity. For Crane, the revealing of identity after an episode of incognito is pivotal in the process of using incognito to prove worth. Lancelot, though, never reveals his identity after winning the tournament in this instance. Lancelot's departure was "so secretive [that] none in the crowd noticed it"; "he had fled lest any recognize him” (Chretien 243). Lancelot does not want to be recognized, he does not seek to incorporate his incognito-actions into his public identity. While anonymity does function to allow Lancelot to prove his worth as even greater than that of his fellows of the Round Table, it allows him to prove his worth in a different way by removing his obligations to fight with the Knights of the Round Table and for the honor and renown of King Arthur and Queen Guinevere. The role of conflicting duties can be seen through Guinevere’s actions when she suspects that the anonymous knight is Lancelot: she asks him to do his worst and lose the first rounds of the tournament, just to test his loyalty. Guinevere eventually tells Lancelot to do his best and he wins the tournament, but she has exemplified the power one has over a knight by knowing his name. Because Guinevere knew Lancelot's identity, he was obliged to obey her commands despite his own desire, which was to prove his worth and earn renown based upon his deeds and not his identification with the Knight's of the Round Table and Arthur's court. Despite Lancelot's desire to prove his worth, avoiding conflicting duties and obligations remain an undeniable factor in concealment of identity and it appears that Lancelot seeks renown and worth that cannot be 
achieved without eliminating these conflicting loyalties. Lancelot seeks renown that is based upon deeds, not nobility, reputation, or social ties.

One of the most identifiable examples of a knight using concealment of identity to prove his worth in Le Morte Darthur is the tale of Sir Gareth. Sir Gareth appears in King Arthur's court on the day of Pentecost, poorly dressed and physically weak. He asks three favors of King Arthur, the first one is for sustenance for 12 months and he will redeem the other two favors in one year's time. King Arthur obliges willingly, sure that he will prove to be of noble blood. King Arthur asks Sir Gareth his name and Sir Gareth replies, “Sir, I cannot tell you” (Malory 121). Arthur's reaction to Gareth's reply is interesting: “'that is marvel,' said the King, 'that thou knowest not thy name, and thou art one of the goodliest young men that ever I saw” (Malory 121). Arthur is sure that Sir Gareth must be noblesse and cannot comprehend why he would not know his name or be willing to reveal it. Gawain and Lancelot agree, with Lancelot chiding Kay for mocking Gareth and saying, "for I dare lay my head he shall prove a man of great worship” (Malory 121). As in any chivalric romance, attractiveness, size, strength and prowess are always signs of nobility. This can be seen in the example of Sir Tor, who is supposedly one of thirteen sons of a cowherd. Tor's father knows that there is something wrong with the qualities of his son:

For I shall tell you, I have thirteen sons; and all they will fall to what labour I put them and will be right glad to do labour, but this child will not labour for nothing that my wife and I may do, but always he will be shooting or casting darts, and glad for to see battles and to behold knights. And always day and night he desireth of me to be made knight. (Malory 52)

The father knows that these are not the qualities of the peasantry; that there is something odd 
about this son. Arthur requires the cowherd to bring in his other sons and recognizes the stark contrast. It is remarked that "Tor was not like him neither in shape nor in countenance, for he was much more than any of them (Malory 52). Tor is more than his brothers; more than his father, more than a manual laborer, more than the lower class. Not to much surprise, Merlin reveals that Tor is actually the son of King Pellinore, who forced himself upon Tor's mother, who kept Tor's true identity a secret (Malory 53). A common theme in both Chrétien and Malory's works is that a noble identity will always eventually become known, even despite the most valiant efforts to conceal identity.

Kay nicknames the still-nameless Gareth "Beaumains,” which connotes that he is a kitchen servant. In one year's time, a damosel comes to King Arthur's court and requests a knight's service to save her Lady. Much to her chagrin, “Beaumains” is granted the adventure. Immediately after he departs, both Kay and Lancelot ride after him. The ever mean-spirited Kay jousts with Gareth, who unhorses him and then proceeds to joust with Lancelot. Both Lancelot and Gareth decide to cease fighting. Under the conditions that Lancelot makes him a knight and keeps his secret, Gareth reveals his name and that he is none other than a brother of Gawain. Even though Gareth’s identity and noble blood have been revealed to Lancelot and the reader, he does not join Arthur’s court. Gareth even reveals his identity again to Sir Persant and his daughter and his dwarf reveals his identity to Sir Gringamore and Dame Lyonesse. (Malory 138139; 149). Only after Gareth has defeated four knights and slain two others in order to save the Dame Lyonesse is his identity finally revealed to King Arthur's court by his mother. King Arthur is overjoyed by the revelation because Gareth has proved himself "a man of worship" and thanks God that Gareth "is proved as worshipful a knight as any” (Malory 156-157).

Although Gareth’s true name and identity are known to all now, Gareth still does not 
join King Arthur's court. King Arthur asks Dame Lyonesse to hold a tournament so that he might find Sir Gareth. Sir Gareth, in turn, goes incognito in the tournament using a magical ring that changes the color of his armor from "white to red and black, that there might neither king nor knight have ready cognizance of him” (Malory 161). Arthur and the Knights of the Round Table wonder at his strength and ability until Gareth's dwarf tricks him into going out undisguised and his identity is discovered. Gareth has already brutally unhorsed his brother Gawain once, but deals him another blow as he rides off into the forest where he and Gawain will both fight unknowingly. After two hours of dealing strokes, the damesol Lyonet reveals their identities to one another and they each lament and give each other "the prize of the battle" (Malory 164). Immediately following, the section ends with Gareth welcomed into Arthur's fellowship, another celebratory joust, and the wedding of Gareth and Dame Lyonesse (Malory $166-168)$.

Although this narrative appears to fit the pattern of Cranes' "semiosis," a moment occurs in which Gareth seems to resist being absorbed into Arthur's fellowship. Before fighting in the tournament, Gareth commands his party so that "in no wise there should none of them tell his name, and make no more of him than of the least knight that there was, 'for,' he said, 'I will not be known of neither more nor less, neither at the beginning nor at the ending'”' (Malory 160). The significance here is Gareth’s emphasis on the ending. Gareth does not want to receive increased honor or renown at the end of the tournament. He does not want to add to his reputation, which Crane argues is the sole purpose of chivalric incognito. When disguised, Gareth's violence towards Gawain is acceptable and unquestioned, but when his identity is revealed Gawain is surprised and resentful of the blow Gareth deals him. When Garth strikes Gawain the second time, Gawain laments, "I weened ye would not have smitten me so" (Malory 
163). The brothers fight with malice and indifference while supposedly unaware of one another's identity, but yield to one another when their identities are revealed. These instances complicate the idea that knight's hide their identities in order to prove their worth. Gareth does not want to modify his identity, but rather avoid it all together. Gareth wishes to avoid the obligations associated with ties to Arthur and his brother Gawain. He refuses to tell Arthur his name, knowing he would require him to remain in his court; he avoids obligations to side with his brethren or at least not fight against them, whom he calls murderous and vengeful, in battle when his identity is known. For Gareth, concealing his identity may lead to renown, but more importantly it temporarily frees him from undesirable duties and obligations and allows him to prove his worth and gain renown free of reputation and expectations.

Another example in Le Morte Darthur where incognito is used to prove worth and gain renown is in the section “A Noble Tale of Sir Lancelot du Lake.” After saving Kay from a dishonorable battle of three knights against one, Lancelot takes Kay's armor while he is sleeping and departs. The narrator provides no insight into Lancelot's intentions, but Kay seems to know exactly what Lancelot intends to do:

Now by my faith, I know well that he will grieve some of the court of King Arthur; for on him knights will be bold, and deem that it is I, and that will beguile them. And because of his armour and shield I am sure I shall ride in peace. (Malory 112)

Kay knows exactly why Lancelot would take on the identity of a lesser knight: so that he can fight against his fellow knights, particularly those who would avoid him because of his renowned strength and prowess. According to Drewes’ argument, by tricking lesser knights into jousting with him, Lancelot is able to further assert the identity that the public has assigned to him; he can 
prove that he is "the best knight" and the "flower of knights" (Malory 99). I argue, rather, that Lancelot is not trying to assert the name that everyone already knows and respects by fighting lesser knights, but trying on a new, previously unavailable role, which is against King Arthur.

Drewes argues that chivalric incognito functions to preserve a knight's name; to uphold the status quo. I suggest that, rather than trying to assert the name and already-possessed power, chivalric incognito serves to allow a knight to gain new, previously-unobtainable power and position by placing himself in direct opposition to Arthur, the greatest and most noble king. During the Middle Ages, men were always in service to their lords; knights and lords were always in service to their kings. Identity very much involved belonging to a group, and many times a group identity involved fealty and service to a particular person (Crane 63-65). The Knights of the Round Table are such a group. The Knights of the Round Table are known as the greatest knights in the world, who serve the greatest king in the world. Much of these knights' renown transfers to King Arthur, though, as their Lord. They fight for his honor and their renown makes Arthur greater. For example, when Lancelot reminds Arthur of the jeopardy and pain he puts his knights through by calling tournaments where other kingdoms fight against his own, Arthur replies, "as for that, I care not; there shall we prove who shall be best of his hands" (Malory 250). Arthur is confident his knights will prevail and win honor and renown in his name and for his kingdom. When a knight fights incognito, though, he is free from his group identity and loyalty to his lord; he is able to claim his renown, based solely in deeds, as his own.

Although Drewes argues that Arthur essentially takes no offense to his knights fighting against him in tournaments because it still adds honor and renown to his name when they perform well and win, I argue that Arthur subtly reveals that he does not appreciate this practice 
towards the end of the work. When Lancelot and Gareth fight together while incognito against Arthur in a tournament, Arthur scolds Gareth, who is his nephew, for leaving his party:

Also King Arthur blamed Sir Gareth because he left his fellowship and held with Sir Lancelot.

“My lord,” said Sir Gareth, "he made me knight, and when I saw him so hard bestead, me thought it was my worship to help him. For I saw him do so much deeds of arms, and so many noble knights against him, that when understood that he was Sir Lancelot du Lake I shamed to see so many good knights against him.”

"Now truly,” said King Arthur unto Sir Gareth, “ye say well, and worshipfully have ye done, and to yourself great worship.” (Malory 443).

In Arthur’s eyes, Gareth has transgressed for two reasons: not only did he fight against his King, but he fought against his family. Unfortunately for Gareth, he was caught between three loyalties: those to his family, his mentor (Lancelot), and his King. In order to choose which loyalties he upheld, Gareth had to join Lancelot in anonymity in order to fight alongside him. This quote portrays the often contradictory nature of chivalric order and values. While Gareth may have betrayed one value, he had to do so in order to uphold another. Arthur later goes on to say that Gareth’s actions are worshipful because a “worshipful knight” always helps a fellow good knight who is in trouble and danger. Arthur does not, though, claim Gareth or Lancelot's worship as his own or contributing to his renown and worship. He tells Gareth that he has gained worship for himself. He does not even congratulate Lancelot, simply telling him, “this day ye have heated me and my knights” (Malory 442). The use of the possessive pronoun "my” seems to almost exclude Lancelot from Arthur’s fellowship at this moment; Lancelot's incognito 
actions have alienated him from Arthur at this time. Lancelot has already fought anonymously against Arthur just shortly before and Gareth has fought against Arthur with Tristram previously as well (Malory 269-272, 415-420). While Arthur makes light of these first-time offenses with laughter and praise, he takes these instances more seriously when they become repetitive patterns.

\section{Conflicting Loyalties and Identity}

When Lancelot and Yvain assume anonymity in Chretien’s works, they gain more freedom to pick and choose their obligations. The example of Gawain serves as an interesting contrast to the anonymous Yvain and Lancelot. In both The Knight with the Lion and The Knight of the Cart, Gawain is assailed by many obligations and duties because of his name and reputation. I find it very interesting that, in these two stories that intersect textually, inquiries about Gawain’s whereabouts and adventures are what hold the two stories together. Whereas Yvain and Lancelot each have their own tale in which they spend much time in disguise, poor Gawain, whose name remains in the open, is even assailed by two separate narratives. In The Knight of the Cart, because of obligations to his King (who is also his uncle) and Queen, Gawain attempts to rescue Guinevere after she is captured by Meleagant. While on this adventure, a woman facing death and distant relatives fearing a giant seek his "great assistance” at King Arthur's court in The Knight with the Lion (Chretien 300, 303). In the same story, Gawain helps a sister who seeks his assistance in a dispute over an inheritance (Chretien 313). Gawain can’t escape his name and reputation; conflicting obligations pile up. On the other hand, Lancelot's anonymity gives him the freedom to solely focus on his quest to "rescue the queen" (Chretien 
196). Although a monk, a vavasor and his sons, and the people of Logres predict that Lancelot will be "liberator of all men and women imprisoned in the land," Lancelot never takes on this obligation (Chretien 193, 196, 199). After the monk identifies Lancelot as the one who will fulfill the prophecy, people begin asking for Lancelot's name. Lancelot carefully protects his anonymity and avoids this obligation, saying that "no other duty" has brought him to the land other than rescuing the Queen; Lancelot makes no promises of freedom to the people of land (Chrétien 196, 211). Had they known his name, this obligation would have been harder to refuse and deflect.

Similarly, Yvain's concealment of his identity, not only allows him to escape the shame he has incurred by neglecting his courtly duties, but allows him to escape his brotherly duties as well. For example, when Yvain and Gawain, who are both concealing their identities, fight to settle an inheritance dispute between two sisters, the question arises as to whether the knights still have loyalty to one another; whether they love or hate each other:

"The two fighters did not recognize each other, though they had loved each other always. Then did they no longer love each other? Yes, I answer you, and no as well...In truth Sir Gawain loved Yvain and called him his companion and...Yvain referred to Gawain in the same way...Yet is hate not equally evident too? Yes, because each would certainly have wished to smash the other's head or shame him so much that he would have been the worse for it...Then did Yvain wish to murder his friend Sir Gawain? Yes, and the feeling was mutual. Would Sir Gawain have killed Yvain with his own hands...? Definitely not...Neither would have hurt or shamed the other...Now I have told a disgraceful lie, for it is most evident that each wished to attack the other with lance raised high in its rest. 
Each was eager to wound or cripple the other, to humiliate him and reduce him to despair...” (Chretien 328-329).

Chretien points out that under normal circumstances, Sir Gawain and Yvain would never have fought or harmed one another because of their duty to each other as brothers in arms. Contrarily, when identity and social obligations become removed—when Yvain and Gawain are no longer functioning under their public identities — their obligations to one another as knights of King Arthur's court become obsolete; they are now opponents, who must defeat the other in order to win. Furthermore, as indicated in the quotation, both Gawain and Yvain want to harm, destroy, humiliate, and perhaps even murder each other in order to win honor, glory, and renown for themselves. The use of the word wish is interesting in this quote, suggesting that perhaps the knights always felt such animosity towards each other, but would never act upon that wish "with their own hands." Upon discovering one another's identity, though, Gawain and Yvain cease fighting. Each laments the battle and claims they would have lost to the other (Chretien 331). This quote best exemplifies an important purpose of concealed identity: when knights disguise themselves or refuse to give their names, they are able to remove themselves from the obligations and duties, whether courtly or brotherly, attached to their identity. Conversely, when knights reassume their identities and names, they find themselves thrown back into their conflicting obligations: Gawain and Yvain can't fight one another because of brotherly duty, but also have an obligation to the ladies they are representing in battle.

In Le Morte Darthur, there are many incognito battles between Knights of the Round Table. All of these incognito battles are similar in one respect: the knights desire to destroy one another only until their names are revealed or they realize they are fighting a brother in arms, just as in the example of Gawain and Yvain cited previously. The best example of this phenomenon 
occurs when Lancelot fights incognito in a tournament against all of the Knights of the Round Table including his own kin (Malory 415-429). Lancelot disguises himself by wearing unknown armor and a red sleeve from a maiden upon his helmet. During the tournament, Lancelot, unknown to all, is grievously wounded by Sir Bors, his cousin. Lancelot, angered by his wound, attacks Sir Bors, Sir Lionel, and Sir Ector with intention to slay them, until he sees their faces: "he might have slain them, but when he saw their visages his heart might not serve him thereto, but left them there” (Malory 419). Lancelot continues to strike down thirty more Round Table knights. When Sir Bors discovers that it is Lancelot he has wounded he laments and apologizes, but Lancelot assures him that no apology is needed, explaining his actions:

For I would with pride have overcome you all. And there in my pride I was near slain, and that was in my own fault, for I might have give you warning of my being there, and then had I had no hurt. For it is an old-said saw, there is hard battle there as kin and friends do battle either against the other, for there may be no mercy, but mortal war. (Malory 428)

Conflicting duties, obligations, and even desires are all brought to light in this example. Out of pride Lancelot sought to prove himself the best of all knights, including the Knights of the Round Table and his family and friends. He refused to warn any of them of his presence because of his desire to earn renown that would become unavailable if anyone knew his identity. For as I have already argued, concealment of identity allows knights the opportunity to gain usually unavailable renown and honor by fighting those who are usually off-limits because of obligations attached to their names and reputations, but also happen to be considered some of the best knights of the world. Lancelot also discusses the difficulty of fighting with kin and friends because knightly values view failure to finish a fight and defeat an opponent as a very shameful 
act. The orders of knighthood laid out by Arthur also forbid Knights of the Round Table from fighting in wrath and killing one another (Malory 57). In concealing his identity, Lancelot escapes these obligations and loyalties only until he sees the person behind the helmet of his opponent. This reveals the greatest instance of concealment of identity of all: the dehumanizing effect of armor that allows knights to forget their own identity as a human and become fighting machines, seeking only glory and honor.

These two examples of anonymous battles illustrate that, when all else is sublimated (love, friendship, kinship, loyalties, obligations, etc.), the need and desire for earning renown and prowess through defeating and/or destroying others in battle is at the root of knightly identity. Maurice Keen writes that in chivalric romances the stereotypical qualities of a knight are always portrayed as prowess, loyalty, generosity, upholding courtly love, of noble birth, and virtuous (Keen 2). Chivalric incognito, though, in these works depicts a new role or identity for knights: that of the "self-seeking" knight. Despite the knightly values and chivalric practices portrayed in these romances, chivalric incognito subverts these values and practices and portrays the earning of renown and prowess through violence and destruction as the core of knightly identity, or rather, the aspect of knightly identity with which knights most identify and care about.

\section{Tristram and Balin in Le Morte Darthur}

The stories of knights outside of Arthur's fellowship such as those of Sir Tristram and Balin are often seen as digressions in Le Morte Darthur because the main purpose of the work is to tell the history and tragic ending of Arthur's kingdom, but I argue that these stories, instead, serve as a counter example to Lancelot, who is critical to King Arthur's court. In an article focused on the Tristram section of Le Morte Darthur, Donald G. Schueler argues that "the story 
of Tristram makes sense in the overall narrative pattern only if it is considered an analogue to the main drama of Arthur's Round Table” (Schueler 53). He argues that the actual story of Arthur's kingdom is merely advanced through subplots and that the main story of Tristram serves as a "counterpoint" to the larger theme of the text (Schueler 53). Schueler holds that Lancelot and Tristram are constantly compared and that there is only one difference between them: their significance to King Arthur's Round Table. "Lancelot is, in a word, indispensable to Arthur's fellowship" (Schuler 55). "The one crucial factor that accounts for all the differences is that Lancelot is a knight whose destiny is connected with the vastly more important destiny of the Round Table fellowship; Tristram's destiny concerns only himself” (Schueler 58). Schueler argues that much of the text is dedicated to demonstrating "Lancelot's rather epic loyalty to Arthur and the Round Table” (Schueler 63). Tristram's and Lancelot's lives parallel in many ways, except for Lancelot's role in the fall of Arthur's fellowship and kingdom.

Tristram and Lancelot mirror each other in many ways: they are both in adulterous relationships with their queens, they often fight incognito, and they are known as equally strong knights. Tristram eventually becomes a knight of the Round Table, but only reluctantly. When Arthur requests that Tristram "abide" in his court, Tristram politely refuses, saying that he has much "to do in many countries." Arthur replies “Not so, ye have promised me, ye may not say nay” (Malory 231-232). Tristram's hesitance to join the Knights of the Round Table speaks to the limiting forces it places upon those who are part of the group. Simply put, Tristram essentially tells Arthur that he is too busy to take on such a large and constricting obligation. Tristram does not dare refuse the most renowned King and reluctantly accepts the invitation. Tristram responds by fighting incognito against the fellowship he has just become a part of. Tristram's going incognito against Arthur's fellowship after becoming a part of it is significant: 
now that he is a part of the fellowship he must disguise his identity when he wishes to fight freely against all knights, thus mirroring the actions of Lancelot. Tristram holds the same view as Lancelot that earning renown is a numbers game that requires defeating the highest number of worshipful knights and that concealing identity in a tournament allows a knight maximum potential to win the tournament. Tristram agrees with Sir Palomides that they should be against King Arthur's party in a tournament because "on his party will be Sir Lancelot and many good knights of his blood with him; and the more men of worship that they be, the more worship [they] shall win” (Malory 260). This quote demonstrates the mentality that I have argued prompts chivalric incognito in Le Morte Darthur: concealment of identity in a tournament and fighting against King Arthur and the Knights of the Round Table allow a knight to gain usually unavailable renown and honor. By removing his ties and loyalties to anyone and everyone through discarding his public identity, a knight can do whatever he desires, which seems to be to prove that he is the best knight of all.

Balin, on the other hand, is not a Knight of the Round Table, but he performs similar actions that both Tristram and Lancelot practice. Balin goes on an adventure that begins in King Arthur's court, finds a magical sword, becomes the Knight with the Two Swords, and fights incognito against his brother, Balan, until they recognize one another. Balin’s narrative follows a similar pattern found in many chivalric romances, except for one difference: Balin’s story goes terribly awry; he and his brother kill one another in battle (Malory 33-49). Most incognito battles between family members and brothers in arms end amicably and happily, but not for Balin and Balan. Andrew Lynch argues that lesser knights like Balin serve an essentially sacrificial purpose for the narrative: basically, other knights must fail so that the great can be great. While it is true that others must fail in order for Lancelot to be the greatest knight, I agree more with Schueler's 
argument that seemingly off-topic stories as those of Balin and Tristram serve to demonstrate Lancelot's defining quality: his significance to King Arthur’s fellowship.

Lancelot's actions have a direct effect on Arthur's fate and the fate of his Kingdom. Knights like Tristram and Balin can fight incognito, have adulterous relationships, and even die without affecting an entire kingdom. The reader does not even learn of Tristram's death at the end of his tale, but only much later in the narrative after the quest for the Sangrail when Tristram has been dead for some time, slain by King Mark. Lancelot's actions, though, directly affect Arthur's Kingdom. Lancelot seems to hold together Arthur's fellowship. When Sir Agravain and Sir Mordred announce that they intend to reveal Lancelot and Guinevere’s adulterous relationship to Arthur, Gawain and Gareth lament: "Now is the realm wholly destroyed and mischieved, and the noble fellowship of the Round Table shall be disparbled” (Malory 469). Gawain argues that many knights and lords will side with Lancelot in the event that Lancelot and Arthur fight, a prediction which proves true when Lancelot departs from Arthur's kingdom (Malory 468, 497). Many also lament Lancelot's departure, arguing that his renown and strength are what kept Arthur's kingdom from danger and ensured peace, which proves true when utter chaos ensues and Mordred takes over the kingdom and wages war against Arthur (Malory 497, 505-510). Unlike Tristram and Balin, Lancelot’s banishment and absence from the Kingdom results in the disbanding of the Knights of the Round Table, war, and much destruction and death.

\section{The Renegotiation of Knightly Identity}

Chivalric incognito renegotiates knightly identity in The Knight of the Cart and The Knight with the Lion in that it paradoxically allows knights to construct a new identity not based 
on Romance naming and reputation conventions, but on deeds. Gordon's article argues that "refusals to give one’s name may in one sense question chivalric roles, courtly hierarchies, and fixed identities”; It “calls into question the value of names and reputations” (Gordon 69, 79). The concealment of identity, then, challenges, or renegotiates, "the nature of knightly identity" (Gordon 70). Gordon contends that when the value of naming and reputation is challenged, "who is who" must be reinterpreted. Gordon concludes by saying that, when naming and reputation conventions are neglected, “knightly deeds become more important than knights' names or the color of their shield" (Gordon 79).

Although The Knight of the Cart and The Knight with the Lion have traditionally been interpreted as works solely concerned with the subject of love and shame incurred through the neglect of love, through analyzing love/shame as a vehicle or catalyst for the concealment of identity, knightly identity then becomes a concern of both works. These works renegotiate knightly identity in that Lancelot's and Yvain's anonymities function to challenge romance conventions of naming and reputation, thus allowing the knights to construct a new identity based solely on deeds. During the twelfth century, knights were expected to fulfill duties to their brothers in arms and courtly duties; duties which often conflicted. This renegotiation of knightly identity through the concealment of public identity in these two works does the cultural work of showing knights in a new role or identity; an identity constructed by deeds rather than naming and reputation. Within the works the tension between identity through naming and reputation and identity based on deeds is constantly brought to light: the men of Logres are "astounded" by Lancelot's prowess because they are "ignorant of the knight's identity" and the family tormented by the evil giant would have had much more affection for the nameless Yvain "had they known of his great valor and courtesy” (Chretien 199, 304). The knights' great prowess seems more 
appreciated in a sincere manner when "greatness" is not expected of them. In these works, the reader sees knights who want a space to be free of the obligations and duties attached to their names and be recognized for their great deeds and prowess. Throughout the story emphasis is continually placed on deeds, with Yvain saying that "good deeds not known are worthless" and Lancelot's “burning desire to show all his valor” (Chretien 242, 307). Lancelot’s and Yvain's honor and renown are attached to their names, and when they abandon these social identities, they are able to gain the honor and renown in prowess they so desperately crave and in ways that may not have been available to them when held back by the obligations and duties that their culture has placed upon them.

Le Morte Darthur renegotiates knightly identity through instances of concealment of identity similar to Chretien's romances. Furthermore, whereas Chretien's romances challenge twelfth century naming conventions, concealment of identity in Le Morte Darthur challenges the values and conventions of Arthur's kingdom and the Knights of the Round Table. This does the cultural work of showing knights in a role not just outside of the Arthurian kingdom, but a role specifically in opposition and resistance to Arthur and the Knights of the Round Table. As in Chretien's works, knights in Le Morte Darthur seek a reputation based on deeds and renown, but this desire forces them to take a position against Arthur's Kingdom and their fellow Knights of the Round Table. The Knights of the Round Table are the best knights in the world and Arthur the greatest Christian King. For a knight like Lancelot, who is known as the epitome of Arthur's fellowship, taking a role in opposition to Arthur is his only way of achieving even more renown and glory; defeating those he fights alongside is the only option Lancelot has left because he has already defeated everyone else.

Le Morte Darthur therefore renegotiates knightly identity in that it depicts knights in a 
role that constructs an identity based on deeds, but in order to achieve this type of identity the knights must take up arms against Arthur's fellowship. Lancelot is depicted as having many obligations, pressures, and duties that are very conflicting and contradictory. Lancelot is Arthur's knight, Guinevere's lover, the lord of his kin, the most-noble knight, the protector of the kingdom, etc. All of these identities pull Lancelot in different directions. When Lancelot is full of doubt after a fight with Guinevere, Sir Bors tells Lancelot “ye must remember you what ye are, and renowned the most noblest knight of the world, and many great matters ye have in hand" (Malory 404). Sir Bors asks Lancelot to remember who he is, but unfortunately Lancelot has too many obligations and impending expectations that intersect and collide, preventing him from forming a unified or coherent identity; Lancelot's numerous "matters in hand" are the problem. Conversely, going incognito allows Lancelot to pursue his own desires. Lancelot realizes that Arthur reaps the benefits of his renown: when Arthur seeks revenge on Lancelot in battle, Lancelot reminds him "remember what I have done in many places, and now I am evil rewarded” (Malory 488). By opposing Arthur, Lancelot is able to claim his own renown and Arthur is unable to bask in Lancelot's glory. The ending of Le Morte Darthur is brought about by a crisis of identity. When Lancelot's and Guinevere's love is revealed, Lancelot is no longer Arthur's knight, all he has done is forgotten by Arthur and those who remember side with Lancelot and leave Arthur's fellowship forever. The confrontation with the idea that public identity is perhaps all a façade breaks up Arthur's kingdom; confrontation with the notion that identity separate from that of name, public reputation, and group identification exists destroys the fellowship of the Round Table. 
Works Cited

\section{Primary Texts}

Chrétien de Troyes. The Complete Romances of Chrétien De Troyes. Ed. David Staines. Bloomington: Indiana University Press, 1990. Print.

Malory, Thomas. Le Morte DArthur: The Winchester Manuscript. Ed. Helen Cooper. Oxford, England: Oxford UP, 2008. Print.

\section{Secondary Sources}

Baron, F. Xavier. "Love In Chrétien's Charrette Reversed Values And Isolation." Modern Language Quarterly 34.4 (1973): 372. Academic Search Premier. Web. 6 Mar. 2013.

Crane, Susan. "Knights in Disguise: Identity and Incognito in Fourteenth-Century Chivalry.” The Stranger in Medieval Society. Ed. F. R. P. Akehurst and Stephanie Cain. Minneapolis, MN: University of Minnesota Press, 1997. 63-79. Print.

Davidson, Roberta. "Prison and Knightly Identity in Sir Thomas Malory's 'Morte Darthur’.” Arthuriana 14.2 (2004): 54-63. JSTOR. Web. 7 Sept. 2013.

Davidson, Roberta. “Reading Like a Woman in Malory’s 'Morte Darthur’.” Arthuriana 16.1 (2006): 21-33. JSTOR. Web. 7 Sept. 2013.

Dosanjh, Kate. “Rest in Peace: Launcelot's Spiritual Journey in 'Le Morte Darthur'.” Arthuriana 16.2 (2006): 63-67. JSTOR. Web. 7 Sept. 2013.

Drewes, Jeanne. “The Sense of Hidden Identity in Malory’s Morte Darthur.” Sir Thomas Malory: Views and Re-Views. Ed. Hanks, D. Thomas Jr. New York City, N.Y.: AMS Press, 1992. 17-25. Print. 
Duggan, Joseph J. "Yvain: Self-Shaming" The Romances of Chrétien De Troyes. New Haven: Yale University Print, 2001. 115-19. Print

Farina, William. "The Birth of Chivalry." Chrétien De Troyes and the Dawn of Arthurian Romance. Jefferson, NC: McFarland \&, 2010. 87-94. Print.

Gordon, Sarah E. "The Man with No Name: Identity in French Arthurian Verse Romance." Arthuriana 18.2 (2008): 69-81. JSTOR. Web. 4 Mar. 2013.

Jesmok, Janet. “Comedic Preludes to Lancelot’s ‘Unhappy’ Life in Malory’s ‘Le Morte Darthur’.” Arthuriana 14. 4 (2004): 26-44. JSTOR. Web. 7 Sept. 2013.

Keen, Maurice. Chivalry. New Haven: Yale University Print, 1984. Print.

Lacy, Norris J. "On Armor and Identity: Chretien and Beyond." De Sens Rassis: Essays in Honor of Rupert T. Eickens. Amsterdam: Rodopi, 2005. 365-74. Print.

Lynch, Andrew. “'Suche a Man I Myghte be’: Good Name, Identity and Narrative.” Malory’s Book of Arms. Suffolk, United Kingdom: D.S. Brewer, 1997. 1-27. Print

Mahoney, Dhira B. “Narrative Treatment of Name in Malory's Morte D’Arthur.” ELH 47.4 (1980): 646-656. JSTOR. Web. 7 Sept. 2013.

Malory, Thomas. Le Morte DArthur: The Winchester Manuscript. Ed. Helen Cooper. Oxford, England: Oxford UP, 2008. Print.

Radulescu, Raluca. “'John Vale’s Book and Sir Thomas Malory’s ‘Le Morte Darthur’: A Political Agenda.” Arthuriana 9.4 (1999): 69-80. JSTOR. Web. 7 Sept. 2013.

Schueler, Donald G. “The Tristram Section of Malory’s Morte Darthur.” Studies in Philology 65.1 (1968): 51-66. JSTOR. Web. 7 Sept. 2013.

Soudek, Ernst. "Origin and Function of Lancelot’s Anonymity in Chretien’s "Chevalier De La Charrette"' The South Central Bulletin 30.4 (1970): 220-23. JSTOR. Web. 4 Mar. 2013. 
Sweeney, Mickey. "Divine Love or Loving Divinely?: The Ending of Malory's 'Morte Darthur’.” Arthuriana 16.2 (2006): 73-77. JSTOR. Web. 7 Sept. 2013.

Uitti, Karl D., and Michelle A. Freeman. Chrétien De Troyes Revisited. New York: Twayne, 1995. Print. 